and making comparisons across different methodologies. Thus, we need pluralistic approaches in addition to traditional study designs that can provide novel information regarding the delivery of CTOs.

\section{Acknowledgements}

We thank Dr Susham Gupta, Dr Peter MacRae and Professor George Ikkos.

\section{References}

Brennan K. J. (2009). Kendra's Law: Assisted Outpatient Treatment in New York. New York State Office of Mental Health.

Burgess P., Bindman J., Leese M., et al (2006) Do community treatment orders for mental illness reduce readmission to hospital? An epidemiological study. Soc Psychiatry Psychiatr Epidemiol, 41, 574-579.

Burns T., Rugkasa J., Molodynski A., et al (2013) Community treatment orders for patients with psychosis (OCTET): a randomised controlled trial. Lancet, 381, 1627-1633.

Callaghan S. \& Ryan C. J. (2016) An evolving revolution: evaluating Australia's compliance with the convention on the rights of persons with disabilities in mental health law. UNSWL], 39, 596.

Churchill R., Owen G., Singh S., et al (2007) International Experiences of Using Community Treatment Orders. Department of Health.

Dale E. (2010) Is supervised community treatment ethically justifiable? J Med Ethics, 36, 271-274.

Dawson J. \& Mullen R. (2008) Insight and community treatment orders. J Ment Health, 17, 269-280.

Dawson J. B. (2005) Community Treatment Orders: International Comparisons. Faculty Of Law, University Of Otago.

Gibbs A., Dawson J., Ansley C., et al (2005) How patients in New Zealand view community treatment orders. J Ment Health, 14, 357-368.
Kisely S. R., Campbell L. A. \& Preston N. J. (2011) Compulsory community and involuntary outpatient treatment for people with severe mental disorders. Cochrane Database Syst Rev, 2, CD004408.

Link B. G., Epperson M. W., Perron B. E., et al (2011) Arrest outcomes associated with outpatient commitment in New York State. Psychiatr Serv, 62, 504-508.

Lofthus A. M., Westerlund H., Bjørgen D., et al (2018) Recovery concept in a Norwegian setting to be examined by the assertive community treatment model and mixed methods. Int J Ment Health Nurs, 27(1), 147-157.

Newton-Howes G. \& Ryan C. J. (2017) The use of community reatment orders in competent patients is not justified. $\mathrm{Br}$ ] Psychiatry, 210(5), 311-312.

Puntis S. R., Rugkåsa J. \& Burns T. (2017) Associations between compulsory community treatment and continuity of care in a three year follow-up of the Oxford Community Treatment Order Trial (OCTET) cohort. BMC Psychiatry, 17(1), 151

Ridgely M. S., Borum J. \& Petrila J. (2001) Does Involuntary Outpatient Treatment Work? RAND Corporation.

Rugkåsa J. \& Burns T. (2017) Community treatment orders: are they useful? BJPsych Adv, 23(4), 222-230.

Rugkåsa J. \& Canvin K. (2011) Community Treatment Orders: a qualitative investigation of patient experiences in England. Psychiatr Prax, 38, 03034259

Steadman H. J., Gounis K., Dennis D., et al (2001) Assessing the New York City involuntary outpatient commitment pilot program. Psychiatr Serv, 52, 330-336. 57

Stensrud B., Høyer G., Granerud A., et al (2015) "Life on hold": a qualitative study of patient experiences with outpatient commitment in two Norwegian counties. Issues Ment Health Nurs, 36(3), 209-216.

Szmukler G. (2015) Is there a place for community treatment orders after the OCTET study? Acta Psychiatr Scand, 131(5) 330-332.
MENTAL HEALTH LAW PROFILE

\title{
The Queensland mental health court: a unique model
}

\section{Suzanne Coghlan ${ }^{1}$ and Scott Harden ${ }^{2}$}

\section{${ }^{1}$ Consultant Child and Adolescent Forensic Psychiatrist, East of England Community Child and Adolescent Forensic Mental Health Service, UK Email: suzannecoghlan@nhs.net ${ }^{2}$ Assisting Psychiatrist, Mental Health Court and Medica Director of Forensic Adolescent Mental Health, Child and Youth Mental Health Service, Children's Health Queensland, Australia \\ Conflict of interest: S.H. is an assisting psychiatrist at the QMHC. \\ Keywords. Forensic mental health services; psychiatry and law: ethics.}

First received 15 Jun 2018
There is a longstanding but sometimes controversial belief that a person is not criminally responsible for a crime if they were suffering from a mental illness at the time of the offence. The Queensland Mental Health Court (QMHC) system, in which assisting clinicians have a central role, is underwritten by this belief. This paper describes the QMHC system.

\section{Background}

Mental health courts have operated in the USA for many years (McNiel \& Binder, 2007; Wolff et al,
2011), the first one having been established in Florida in 1997 (Mikhail et al, 2001). Mental health courts also exist in Canada. However, to our knowledge, the process of the Queensland Mental Health Court (QMHC) model is unique worldwide. In Australia, individual states have legislative jurisdiction over a number of issues, including criminal justice and mental health systems. Legislation governing these areas is separate for each state. The current QMHC system was established as part of the Mental Health Act in 2000, the similar precursor Mental Health Tribunal having been established in 1985 (Queensland Government, 2014; State of Queensland, 2015). The recently updated Mental Health Act 2016 (which came into effect in March 2017) continued the QMHC, 
Final revision 7 Feb 2019 Accepted 8 Mar 2019

doi:10.1192/bji.2019.11

(c) The Authors 2019. This is an Open Access article, distributed under the terms of the Creative Commons Attribution-

NonCommercial-NoDerivatives

licence (http://creativecommons.

org/licenses/by-nc-nd/4.0/), which permits non-commercial re-use,

distribution, and reproduction in

any medium, provided the

original work is unaltered and

is properly cited. The written

permission of Cambridge

University Press must be obtained

for commercial re-use or in orde

to create a derivative work. with some amendments (State of Queensland, 2018). The QMHC operates at the Supreme Court level and primarily determines cases where queries exist regarding insanity or unfitness for trial.

The Ministry of Justice in England and Wales completed a feasibility study to see whether a mental health court system, a diversionary model based at the magistrate level, would be worthwhile in terms of reducing reoffending rates and improving access to mental health services for offenders and defendants (Pakes et al, 2010). In this model, defendants, if guilty, would be held criminally responsible for their actions; therefore, it is not comparable to the QMHC model.

\section{Structure and process}

The QMHC is presided over by two Supreme Court Justices, who sit separately. Prior to the recent Mental Health Act, each judge was assisted by two independent forensic psychiatrists (Queensland Government, 2009, 2014), each of whom were selected from a panel of seven psychiatrists chosen by the court on the basis of their qualifications/experience and appointed for 3 year terms. The recent changes to the Mental Health Act mean that the assisting clinicians may be either psychiatrists or clinicians who have experience of caring for individuals with an intellectual disability. A psychiatrist cannot assist the court in cases where they have previously

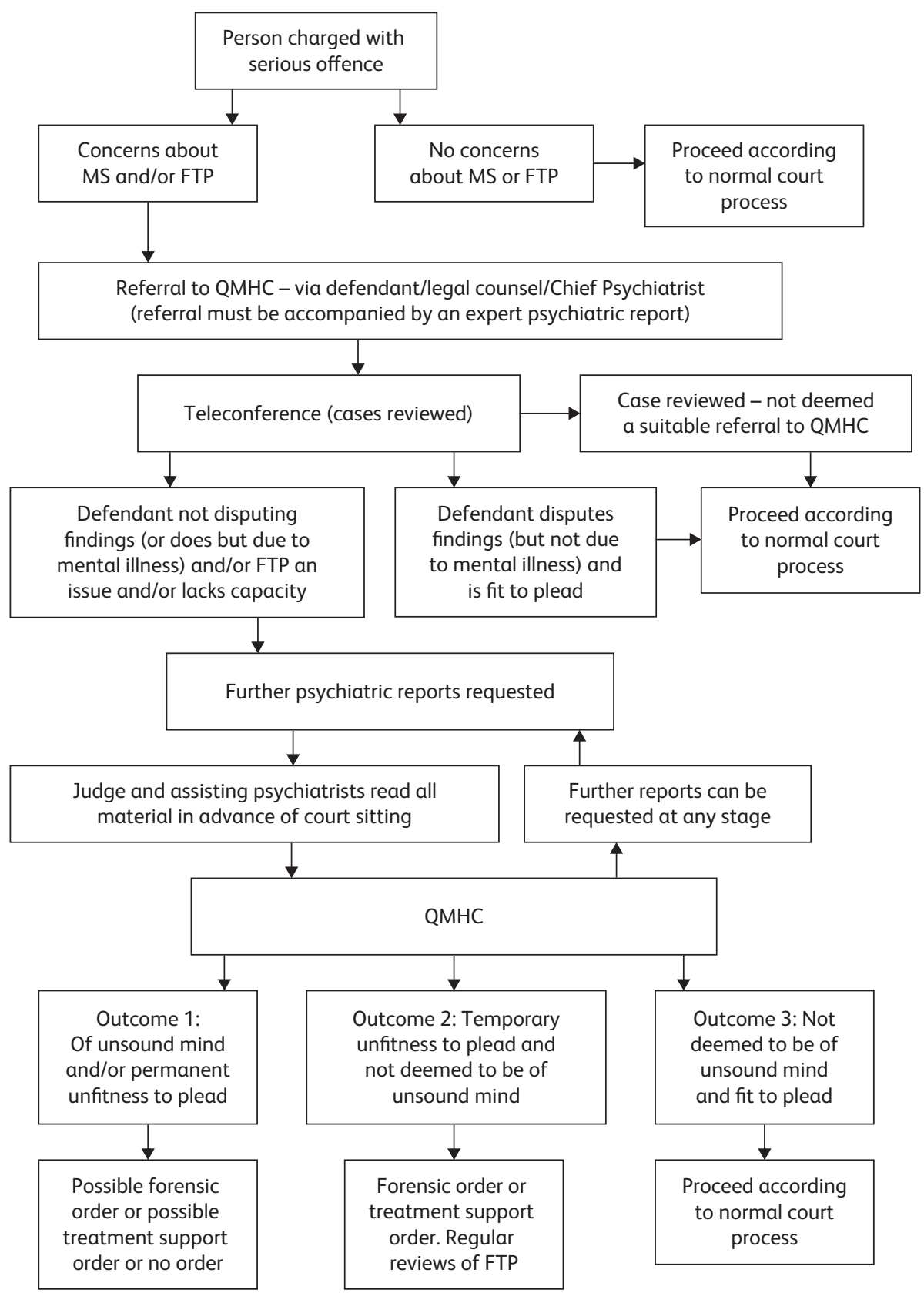

Fig. 1

Outline of the QMHC Process Pathway. FTP, fitness to plead; MS, mental state. 
Table 1

Some differences between the QMHC and the current model in England and Wales

\begin{tabular}{|c|c|}
\hline QMHC & England and Wales \\
\hline $\begin{array}{l}\text { All expert reports must be disclosed to the court even if they are detrimental to a } \\
\text { mental health defence. }\end{array}$ & Both sides do not necessarily see all expert reports that are commissioned. \\
\hline $\begin{array}{l}\text { This system is noticeably more dependent on psychiatric evidence, compared with } \\
\text { the normal criminal court process. The clinicians assisting the judge are not } \\
\text { considered expert witnesses. The clinicians do not meet the defendant but rather } \\
\text { review the documentation in the case, hear the evidence put before the Court, and } \\
\text { subsequently give their opinion in open court on the issues of fitness to plead, } \\
\text { soundness of mind and clinical management as assistance to the judge. }\end{array}$ & Psychiatrists act as either expert or professional witnesses. \\
\hline $\begin{array}{l}\text { Defendants do not enter a plea. Not disputing evidence does not equate to entering } \\
\text { a guilty plea. }\end{array}$ & Defendants enter a plea, unless deemed unfit to plead. \\
\hline $\begin{array}{l}\text { Defendants are not convicted of a crime if they are deemed to have been of unsound } \\
\text { mind at the time of the alleged offence }\end{array}$ & $\begin{array}{l}\text { Defendants are convicted if they are found to be guilty of a crime (except in a small } \\
\text { number of cases, where there is a finding of 'not guilty by reason of insanity'). Issues } \\
\text { relating to soundness of mind become pertinent at the time of sentencing, when } \\
\text { consideration is given to the most appropriate disposal. }\end{array}$ \\
\hline $\begin{array}{l}\text { A trial of the facts does not occur in cases where the defendant is deemed to be unfit } \\
\text { to plead for a period of time. There are regular reviews of fitness to plead to a point. }\end{array}$ & $\begin{array}{l}\text { A trial of the facts can proceed if the defendant is deemed to be unfit to plead/take } \\
\text { part in court proceedings over a period of time. }\end{array}$ \\
\hline $\begin{array}{l}\text { If a prisoner is transferred from prison to a secure mental health in-patient unit for } \\
\text { treatment, they are transferred back once hospital treatment is completed. }\end{array}$ & $\begin{array}{l}\text { Prisoners who are transferred to secure mental health in-patient units for treatment } \\
\text { sometimes remain there/do not return to prison. A person can receive a mental } \\
\text { health treatment order disposal if they become mentally ill after the time of the } \\
\text { offence and before sentencing, such that it is felt that hospital in-patient treatment } \\
\text { is required. }\end{array}$ \\
\hline
\end{tabular}

had any substantive involvement with the defendant.

At each sitting of the QMHC, there are up to four different sets of legal representatives present (representing the defendant, the Department of Health, the Director of Forensic Disability and the Director of Public Prosecutions). The defendant attends in person or via videolink.

The QMHC considers the following issues (Queensland Government, 2009; State of Queensland, 2015): whether the defendant was 'of unsound mind' at the time of the alleged offence; whether a diminished level of responsibility applies (in cases of alleged homicide); and fitness to plead/fitness for trial. It also hears appeals against Mental Health Review Tribunal findings.

Figure 1 outlines the process pathway - referrals can also be made by the Director of Public Prosecutions, by the Director of Forensic Disability, by a Court or by the Attorney General. A case can be referred to the QMHC if there are suspicions that the defendant is or was mentally ill and/or has an intellectual impairment such that, at the time of the alleged offence, they were 'of unsound mind' and/or that they are currently felt to be either temporarily or permanently unfit to plead, owing to mental illness and/or intellectual disability. A finding of 'of unsound mind' is made when the QMHC deems that someone, as a result of mental illness and/or intellectual impairment, was not able to understand what they were doing, could not control their actions, and/or did not know that they should not have committed the act or omission (based on the McNaughton rules). If that is the case, the defendant is acquitted and relevant treatment options are considered. It should be noted that the Queensland Mental Health Act states that: 'unsound mind does not include a state of mind resulting, to any extent, from intentional intoxication or stupefaction alone or in combination with some other agent at or about the time of the alleged offence' (State of Queensland, 2018).

If a defendant is deemed unfit to plead, the Court must then decide whether this unfitness is permanent. Where unfitness to plead is considered likely to be temporary, the Court is required to make either a forensic order or a treatment support order. Regular reviews of fitness to plead are conducted for a period of approximately 3 years (with the exception of cases involving offences carrying a potential sentence of life imprisonment, in which defendants are reviewed over a longer period). The Attorney General can discontinue or defer such review proceedings.

Once a referral is made to the QMHC, criminal court proceedings are suspended, with the exception of decisions regarding bail. If there is a dispute about whether the person committed the offence and there are no concerns about their fitness for trial, the QMHC should not

Table 2

Productivity of the QMHC

\begin{tabular}{|c|c|c|c|c|c|}
\hline Year & $\begin{array}{l}\text { Total number of } \\
\text { matters heard }\end{array}$ & $\begin{array}{c}\text { Number of } \\
\text { references (total) }\end{array}$ & $\begin{array}{l}\text { Number of references } \\
\text { related to alleged homicide }\end{array}$ & $\begin{array}{c}\text { Number of } \\
\text { appeals }\end{array}$ & $\begin{array}{l}\text { Number of days } \\
\text { the court sits }\end{array}$ \\
\hline $2015 / 2016$ & 268 & 217 & 6 & 47 & 52 \\
\hline $2016 / 2017$ & 291 & 243 & 7 & 48 & 49 \\
\hline
\end{tabular}


consider the issues regarding soundness of mind, unless the dispute is considered attributable to mental illness, or the alleged offending involved any of the following: killing on provocation, diminished responsibility for murder, or killing for preservation in an abusive relationship (State of Queensland, 2018).

Table 1 highlights some of the key differences between the QMHC and the system in England and Wales.

\section{Advantages}

- The QMHC model is less adversarial and potentially more time- and cost-efficient. Each case is allocated a time slot, depending on complexity. A less complex case, with agreement between experts, may be processed by the court in $20 \mathrm{~min}$, whereas serious contested cases (such as alleged homicide) may last for days. Table 2 outlines the productivity of the QMHC in recent years (Queensland Courts, 2017).

- Defendants retain the right to a criminal trial. A mental health defence can still be presented if a case is subsequently heard in the criminal court setting. In such cases, the decision of the mental health court is not disclosed to the jury.

- The frequent use of videolink and tele-evidence is a striking feature of the QMHC. Videolink allows professionals and defendants to be questioned without the delay associated with travel (Queensland is the second largest state in Australia and witnesses can be up to $1500 \mathrm{~km}$ from the Court). If there is consensus among the different parties regarding the finding in a case, evidence may not need to be heard.

- Any psychiatric/clinical report relevant to the case, to which the referrer has access, is submitted at the point of referral. This applies even if any information therein will adversely affect the case.

- The QMHC is allowed to consider a wide variety of materials as evidence, such as hearsay evidence and victim statements.

- In most cases where the defendant receives a forensic order, the victim is informed about where the defendant is placed, when they are to be reviewed, and whether they are to receive community treatment. There is a specific victim support service.

\section{Challenges}

- Critics may argue that the QMHC system allows the defendant to forego taking responsibility for their actions. Pragmatically, serious offences will usually result in forensic orders being made that will restrict the liberty of the individual for some years, or even permanently, if they remain unwell and a risk to the community. Each year in England and Wales, a small number of criminal cases result in a finding of not guilty by reason of insanity - 26 cases and 29 cases in 2015 and 2014, respectively (Freedom of Information request).

- A significant dispute of the facts unrelated to mental illness results in no findings and the case being returned to the criminal court.

- Financial constraints mean that the number of reports that can be commissioned by experts each month is limited; this can lead to some delays in cases being processed.

\section{Conclusion}

The key difference between the QMHC system and the current system in England and Wales is an ethical one - although reasons for considering change may be pragmatic in nature. Should people who commit crimes when they are deemed to have been 'of unsound mind', or who are unfit to plead owing to mental illness and/or intellectual disability, be convicted of said offences?

\section{References}

McNiel D. E. \& Binder R. L. (2007) Effectiveness of a mental health court in reducing criminal recidivism and violence. American Journal of Psychiatry, 164(9), 1395-1403.

Mikhail S., Akinkunmi A. \& Poythress N. (2001) Mental health courts: a workable proposition? Psychiatric Bulletin, 25, 5-7.

Pakes D. F., Winstone J., Haskins J., et al (2010) Mental Health Court Pilot: Feasibility of An Impact Evaluation. Available at: http://www. ohrn.n/resource/policy/MentalHealthCourts2010.pdf.

Queensland Courts (2017) Mental Health Court: Annual Report 2016-2017. Queensland Courts. Available at: http://www. courts.qld.gov.au/_data/assets/pdf_file/0007/541249/ mhc-ar-2016-2017.pdf.

Queensland Government (2009) What are the Main Parts of Queensland's Forensic Mental Health System? Fact Sheet 4. Available at: https://www.health.qld.gov.au/_data/assets/pdf_file/0034/ 436696/ind_fs4.pdf.

Queensland Government (2014) The Mental Health Court. Available at: https://www.health.qld.gov.au/_data/assets/pdf_file/0036/ 444888/mhc-factsheet.pdf.

State of Queensland (2015) Mental Health Act 2000. State of Queensland. Available at: https://www.legislation.qld.gov.au/view/pdf/ repealed/2015-09-01/act-2000-016

State of Queensland (2018) Mental Health Act 2016, Act No. 5 of 2016. State of Queensland. Available at: https://www.legislation.qld. gov.au/view/pdf/inforce/current/act-2016-005.

Wolff N., Fabrikant N. \& Belenko S. (2011) Mental health courts and their selection processes: modeling variation for consistency. Law and Human Behavior, 35(5), 402-412. 